\title{
FORMATION OF A SYSTEM OF REGULATIONS IN THE CUSTOMS SPHERE
}

\section{Dorofeieva L. M., Korneva T. V.}

\section{INTRODUCTION}

Having chosen the European path of development, Ukraine has determined the strategic direction of its internal and external policy to integrate into the European Community. On the whole, the processes of unification have been characteristic of public relations around the world for more than half a century, but only EU countries have reached the level that has allowed them to form not only an economic but also a customs union.

One of the determining factors that gives stability to the functioning and development of the European Union is legal organization, which is a qualitatively new form. This is a new legal order that is different from the international law and the internal law of the states, it's a synthesis of the interaction of the relevant norms of international law, legal regulations and jurisprudence of the European Union. The abovementioned rule of law of the European Union creates the so-called "acquis communautaire" that regulates mainly the economic sphere of integration activities of the association. The role of rule of law plays not only the legal core of European economic integration, but also the creation of a legal framework which regulates the relations of the EU with other subjects of international law, especially the so-called third countries, which include and Ukraine'.

Bringingnationallegislation, includingcustoms, toEuropeanrequirements and standards will not only accelerate the process of European integration of our society, but also create favorable conditions for the development of cross-border trade ${ }^{2}$. And the globalization of administrative law has tremendous potential for improving the quality of national administrative law and is capable of contributing to the modernization of the entire legal system of the state ${ }^{3}$.

\footnotetext{
Денисенко В.В. Правове забезпечення митної політики: міжнародно-правові стандарти та українське законодавство : навчальний посібник. Запоріжжя : ЗНТУ, 2018. 326 с. С. 6-7.

2 Василенко В.М. Реалізація принципу «єдиного вікна» у здійсненні контролю за переміщенням окремих видів товарів через митний кордон України. Форум права. 2015. № 1. C. $38-41$. C. $40-41$.

Кормич Б.А. Глобалізація адміністративного права та митне законодавство. Lex Portus. № 5 (7). 2017. C. 17-29. C. 28.
} 
The process of integration of Ukraine into the European space is complicated, complex and long-lasting, since it envisages, in addition to changes in the rules of national law, changes in the organization of activity of state bodies and in society as a whole.

In international law as "de facto" system of standards governing various aspects of international relations has already been established and is successfully operating. While agreeing that it makes sense today to ensure that customs legislation is developed in the best possible harmony with world and European standards ${ }^{4}$, in the course of this scientific research, we will try to clarify, first of all, issues related to the regulation of customs relations in national law.

\section{General principles of legal regulation of modern customs relations}

Let's consider the main elements of Ukrainian customs legislation in view of the form of sources and the legal personality of the state bodies empowered to adopt them.

One of the most important elements of the European integration processes, to which Ukraine has actively joined at the end of the last century, is an effective and stable legislative framework that meets international requirements and standards. Confirmation that Ukraine's integration into the European legal space is accompanied by a large-scale reform of Ukraine's legal system, we also can find in Yu. Akimenko, who stresses that the country's international obligations require the development of new national legislation, focused on European legal standards, which are set out in the relevant Council of Europe legal documents and European Union legislation ${ }^{5}$, O. Goryunova ${ }^{6}$ and V. Gomonay ${ }^{7}$. At the same time

\footnotetext{
4 Акіменко Ю.Ю. Деякі аспекти гармонізації національного законодавства, що регулює діяльність господарських товариств у контексті створення зони вільної торгівлі між Україною та Європейським Союзом. Зона вільної торгівлі Украӥна - Свропейський Союз та європейська інтеграція: правові та економічні аспекти: зб. статей учасників міжнар. наук.-практ. конф. (м. Одеса, 08 черв. 2007 р.) / відп. ред. М.П. Орзіх; Одеська національна юридична академія; Б-ка журналу «Юридический вестник». Одеса : Фенікс, 2007. С. 75-79.

5 Акіменко Ю.Ю. Деякі аспекти гармонізації національного законодавства, що регулює діяльність господарських товариств у контексті створення зони вільної торгівлі між Україною та Європейським Союзом. Зона вільної торгівлі Украӥна - Європейський Союз та європейська інтеграчія: правові та економічні аспекти: зб. статей учасників міжнар. наук.-практ. конф. (м. Одеса, 08 черв. 2007 р.) / відп. ред. М.П. Орзіх; Одеська національна юридична академія; Б-ка журналу «Юридический вестник». Одеса : Фенікс, 2007. С. 75-79.

6 Горюнова Є.О. Євроінтеграція : навчальний посібник. Київ : Академвидав, 2013. 224 с.

7 Гомонай В.В. Зближення законодавства України з правовою системою Європейського Союзу. Держава і право. Юридичні і політичні науки : зб. наук. праць. Київ : Ін-т держави і права ім. В.М. Корецького НАН України, 2009. Вип. 44. С. 204-212.
} 
in international law "customs legislation" is considered as a set of laws and regulations which relating to the importation, exportation, movement or storage of goods, the application and enforcement of which is vested directly in the customs service, as well as any regulations issued by the customs service within its competence ${ }^{8}$.

As worldwide, customs authorities are responsible for the direct implementation of customs in Ukraine that actually enforcing customs legislation, these authorities have the exclusive competence for its implementation, and execution responsibility for the completeness of the state customs legislation. At the same time, the customs authorities are the object of customs management, the subject of such management is the state, and the legislation of public customs is a management tool.

V. Nastyuk noted that the system of customs legislation is an independent logical set of normative legal acts of sectoral affiliation, which are established by the state and are intended to regulate public relations related to the movement of goods and vehicles across the customs border, collection of customs duties, customs clearance and control and other means of conducting customs policy ${ }^{9}$.

The administrative and legal regulation of the activities of the customs authorities as a whole develops in accordance with the general approaches to the ordering of public relations. Therefore, to clarify its specificity, first of all it's necessary to consider the essence of legal regulation as a structural element of the legal system and the views of scientists on this phenomenon.

The origin of the term "regulation" is associated, first of all, with the Latin word "regulo", i.e. "rule" and is understood as ordering, bringing something into line with something ${ }^{10}$. At the same time, legal regulation covers different sides of public life, and the legal form is inherent in the main and most important types of public relations in those areas of human activity that, in addition to the legislative form, require its substantive legal completeness ${ }^{11}$.

Most often, legal regulation in the legal literature is understood as one of the main means of state influence on public relations in order

\footnotetext{
8 Міжнародна конвенція про спрощення та гармонізацію митних процедур у редакції від 26 червня 1999 р. Офіиійний вісник Украйни. 2011. № 71/№ 18. Ст. 727, Ст. 2711. Р. 2 Загального додатку Конвенції.

9 Настюк В.Я. Адміністративно-правові проблеми законодавчого регулювання митної справи в Україні : автореф. дис. ... д-ра юрид. наук. Харків, 2005. 36 с. С. 14.

10 Скакун О.Ф. Теорія держави і права : підручник / пер. 3 рос. Харків : Консум, 2006. 656 c. C. 489.

11 Ярмакі Х.П. Адміністративно-наглядова діяльність міліції в Україні : монографія. Одеса : Юрид. л-ра, 2006. 366 с. С. 32.
} 
to streamline them in the interests of person, society and the state, and the legal dictionary classifies legal regulation as the process of influence of the state on public relations by means of legal norms (norms of law). Although the views of legal scholars differ in approach and formulation, they formalize a virtually uniform notion of legal regulation, which can be defined as a system of different methods, forms and means of legal influence of the state on the behavior of participants in public relations in order to oblige participants of such relations, the scale of behavior in society. Despite some differences, scientists have agreed that the mechanism of legal regulation is implemented through the use of legal (legal) means and is intended to ensure the regulation (ordering) of social relations.

The derivative category of general legal regulation, its sectoral variety is administrative and legal regulation, which can be characterized as a process of consistent use of administrative legal means to achieve the goals of regulating the behavior of participants in public relations. Administrative and legal regulation differs in the branches through an independent mechanism of ensuring such regulation: peculiar approaches and means of influence of law on public relations.

In the period of active reformation of the system of public administration authorities and based on the purpose of our research, we consider it necessary to turn to a separate direction - administrative and legal regulation in the customs sphere, and to distinguish the entities that participate in the administrative and legal regulation of the customs sphere, and enter in legal relations with the subjects of public administration. As you know, the subject of administrative and legal regulation in the customs sphere are public authorities, which, in accordance with the competence defined by the law, performs managerial functions in order to ensure the realization of public interest in the customs sphere. The highest executive authority in the system of public authorities of modern Ukraine is the Cabinet of Ministers of Ukraine. Specialized entities are the Ministry of Finance, as the main administrative structure with special competence for the formation of the state customs policy, the sphere of activity of which extends to the whole state, and the State Fiscal Service, which is responsible for the implementation of such policy.

Describing the subjects of administrative legal regulation of customs scientists believe that the traits that define their essence is the same type with those inherent in the subjects of administrative and legal regulation in general. At the same time, the common features of these entities include: expressing the interests of a particular social community; the existence 
of systemic organization in structure, functions and activities; the presence of functions inherent only to them, but within the limits of their own activity of performing general management functions; own legally sound organization; a certain place in the hierarchy of the state apparatus, the authority to make clearly defined types of decisions ${ }^{12}$.

O. Ivanov considers that administrative and legal regulation in the customs sphere is the process of purposeful, normative and organizational influence of norms of administrative and customs law and other administrative means of securing the rights and legal interests of individuals, legal entities and the state in public relations in the customs sphere cases for the purpose of subordination to their legally established order, as well as the establishment and maintenance of the order of movement of goods and vehicles across the customs border of Ukraine ${ }^{13}$. Focusing both on the regulatory and the security impact of regulations on public relations in the customs sphere, V. Komzyuk defined the legal regulation as an activity of the customs authorities and offered to understand the effective, normative and organizational influence on the public relations, implemented by the whole system of legal means and forms, which are the customs authorities for the purpose of ordering, developing and protecting them in accordance with the need to ensure the efficiency of customs and the implementation of state customs policy, as well as the application of measures of state influence violators of customs rules and regulations ${ }^{14}$.

In the current conditions of rapid changes of legislation, active reform of the central executive authorities, including in the sphere of formation and implementation of customs policy, as well as strengthening of administrative influence of governmental structures on the activity of customs bodies, this concept needs clarification. At the same time, we suggest that not only the customs authorities are the subjects of legal relations in the customs sphere. For example, since June 21, 2018, the Government has introduced an experimental project to prevent the evasion of payment of customs duties, during which time the right to stay in customs control zones at border crossing points and other places where customs formalities are carried out, as well as the right of access to the automated customs

12 Глазунова Н.И. Государственное управление как система: монография. Москва : Изд-во Гос. ун-та управления, 2001. 373 с. С. 96.

13 Іванов О.В. Суб'єкти адміністративно-правового регулювання в галузі митної справи : дис. ... канд. юрид. наук. Запоріжжя, 2015. 205 с. С. 34.

14 Комзюк В.Т. Адміністративно-правовий статус митних органів України : дис. ... д-ра юрид. наук. Харків, 2014. 446 с. С. 83. 
clearance system was given to the police ${ }^{15}$. As a result of the implementation mechanism of the "single window" to the entities carrying out customs formalities other than the customs authorities classified as other government agencies, institutions and organizations authorized to carry out licensing or control functions for moving goods across the customs border of Ukraine ${ }^{16}$. As a result of organizational changes and redistribution of functions between the territorial bodies of the State Fiscal Service from 2013 to 2020 , the authority to carry out documentary checks of compliance with the requirements of the legislation on state customs (post-audit control) from customs was transferred to the departments of the main departments of the State Fiscal Service in the regions.

Therefore, under the legal regulation of the activities of customs authorities in modern conditions, we propose to consider the regulatory and organizational impact on public relations in the field of state customs and the implementation of state customs policy, the subjects of which are the bodies of the State Customs Service, law enforcement and other state bodies, institutions and organizations authorized to exercise permitting or control functions for the movement of goods, vehicles for commercial purposes across the customs border of Ukraine, which is provided by a complex of legal means aimed at systematization and improvement of such relations, as well as ensuring effective influence against violators of customs and other legislation.

As you know, the legal framework of each country is shaped by the influence of national traditions and sustainable approaches both to the formation of a system of state bodies and to the creation of legal sources that regulate certain social relations. The subjects of adoption of normative legal acts in legal relations of the customs sphere should have sufficient powers for their preparation and formalization. It shouldn't be forgotten that the development of domestic customs legislation is largely determined by the level of international customs cooperation, which is called one of the main factors in the development of customs in the country ${ }^{17}$; Customs

15 Про реалізацію експериментального проекту щодо створення умов для унеможливлення ухилення від сплати митних платежів : Постанова Кабінету Міністрів України від 20.06.2018 p. № 479. URL: http://zakon.rada.gov.ua/laws/show/479-2018.

16 Про внесення змін до Митного кодексу України та деяких інших законів України щодо запровадження механізму «єдиного вікна» та оптимізації здійснення контрольних процедур при переміщенні товарів через митний кордон України : Закон України від 06.09.2018 p. № 2530-VIII. URL: http://zakon.rada.gov.ua/laws/show/2530-19.

17 Клян Ф.Г. Міжнародно-правове регулювання переміщення товарів через митний кордон : дис. ... канд. юрид. наук. Київ, 2011. 197 с. С. 80. 
law is based on both domestic and international legislation ${ }^{18}$, and in the course of its implementation customs is updated, adapted to the new conditions of socio-economic life of the state and the international community, which requires constant updating of its regulatory and legal subsystem ${ }^{19}$.

International organizations, which have repeatedly monitored the activities of the customs authorities of Ukraine, stated that the customs legislation, which came into force on January 1, 2004, to some extent follows the models of activity of the EU legislation, but the principles of the former economic and political system were still present in the Customs Code. Such situation was explained by the fact that the Customs Service of Ukraine and its partners paid attention mainly to urgent problems, "patching holes" or adopting provisions on approximation to EU norms. It doesn't take into account the need to reform and modernize legislation which must comply general international best practices, and the process of bringing Ukraine customs legislation into line with current international practice is accompanied by tightening and difficulties ${ }^{20}$. Over the past 15 years, little has changed, and although Customs Code of Ukraine 2012 included a much more international standard, but change is not complex, and the scientific approach is inferior to political interests.

Scientists are convinced that since in the customs sphere international law influence on national laws has a relatively long history, it is not surprising that a number of rules and principles, which are nowadays considered common to national customs legislation, have in fact been formed at the interstate level.

B. Kormich noted that the first examples of the formation of universal norms were in 1923, when the International Convention on the simplification of customs formalities ${ }^{21}$ was signed, and the most important feature of the 1923 Convention was that the vast majority of its norms was not only sufficiently progressive at that time, but also aimed at establishing uniform rules and standards for the domestic law of the participating countries. Thus, the scientist identifies several main groups of instruments of influence on the national customs legislation:

\footnotetext{
18 Русских Т.В. Концепція норм м'якого права у сфері регулювання митних відносин в Україні : дис. ... канд. юрид. наук. Одеса, 2015. 176 с. С. 24.

19 Коломоєць О.В. Митна функція сучасної української держави: загальнотеоретичне дослідження : дис. ... канд. юрид. наук. Одеса, 2014. 205 с. С.83.

20 Ладлоу Г., Дженкінз Д., Морт Е. Реформування Державної митної служби: звіт місії відділу бюджетно-фінансових справ (ВБФС). Міжнародний валютний фонд. Січень, 2006. 110 c. C. 37.

21 International Convention Relating to the Simplification of Customs Formalities. Geneva, November 3, 1923. League of Nations. Treaty Series. Vol. 30. 1924-1925. P. 371.
} 
1) establishment of sectoral principles of state regulation of foreign trade. In particular, the following principles were introduced: the absence of obstacles through excessive, unnecessary or arbitrary customs or other similar formalities (Article 1); fair treatment in the application of customs or other similar formalities and abstention from unfair trade discrimination in other participating countries (Article 2);

2) recommendation norms on the procedure of implementation of administrative procedures related to customs regulation: issuing of import and export licenses (Article 3), submission of certificates of origin of goods (Article 11), organization of customs clearance (registration in internal customs, registration outside the working place) sometimes) (Article 14);

3 ) direct establishment of the procedure for temporary importation of commercial samples, including the forms of necessary documents (Article 10);

4) establishment of provisions on mutual recognition of administrative acts, in particular, encouraging the conclusion of agreements on mutual recognition of certificates of conformity (Article 13), introduction of provisions in the domestic legislation on the recognition of seals and seals of customs authorities of other countries imposed on goods in transit and customs warehouse (Article 14);

5) establishment of a group of imperative norms aimed at protecting the rights of FEA subjects: proper publication of customs legislation acts in advance or at least simultaneously with their entry into force (Articles 4, 5, 6); compensation through administrative, judicial or arbitration proceedings for losses due to misapplication of legislation by the customs administration (Article 7); enabling the release of goods into circulation before settling disputes on payment of duties (Article 8) ${ }^{22}$.

\section{Development of legal regulation in the context of institutional development of customs authorities of Ukraine}

Against the background of Ukraine's active participation in international cooperation and deepening of European integration processes, there was an urgent need to create a unified, transparent and understandable for all participants in customs relations, regulatory framework. In our opinion, today there are a large number of insufficiently systematic sources of law that do not always effectively affect not only the activities of customs and other controlling bodies, but also society as a whole. Considering

22 Кормич Б.А. Глобалізація адміністративного права та митне законодавство. Lex Portus. № 5 (7). 2017. С. 17-29, 21-22. 
the legal regulation of the activities of customs authorities in the context of their institutional development, let's try to find out the peculiarities of the regulatory framework, through which the public relations that arise about the movement of certain objects across the customs border of Ukraine are influenced. First of all we should define the term "customs legislation", which we are beginning to analyze. We noted that this institution is represented by a wide range of legal acts of different legal force and different external forms of expression, therefore customs legislation should be investigated on the basis of a broad understanding of this term. Although some scholars argue that customs legislation should be considered in the narrower sense, but its contents are only customs law expressed in the legislation ${ }^{23}$, we believe that the extremely wide range of issues related to customs matters regulated by subordinate regulations.

According to experts, the most significant group of sources of administrative law are the legal acts that form a system, which are built in accordance with the principle of the rule of law. The place of a specific source of administrative law in this system is defined by the notion of "legal force", which characterizes the degree of subordination of normative legal acts: all of them are based on the norms of the Constitution and laws of Ukraine, which have supreme legal force; regulatory acts of higher executive bodies serve as the legal basis for acts adopted by lower level bodies; regulatory acts of central executive bodies have a larger scope of action than acts of lower level bodies; regulatory acts of a sectoral (departmental) nature are based on national sources ${ }^{24}$.

The legislation of Ukraine on the issues of the state customs affairs consists of the Constitution of Ukraine, the Customs and Tax Codes of Ukraine, other laws of Ukraine that regulate the issues of customs affairs, international treaties of Ukraine, as well as normative legal acts issued on the basis and on the implementation of the Customs Code of Ukraine, and other legislation ${ }^{25}$. As you can see, cited in Art. 1 of the Customs Code of Ukraine is not exhaustive.

As in other branches of law, customs law rests on a constitutional basis and on the Constitution itself, which is a platform, a solid basis for

\footnotetext{
23 Настюк В.Я. Адміністративно-правові проблеми законодавчого регулювання митної справи в Україні : автореф. дис. ... д-ра юрид. наук. Харків, 2005. 36 с. С. 17.

24 Авер'янов В.Б. Вибрані наукові праці / упоряд.: О.Ф. Андрійко, В.П. Нагребельний, Л.Є. Кисіль та ін. ; за заг. ред. Ю.С. Шемшученка, О.Ф. Андрійко. Київ : Ін-т держави і права ім. В.М. Корецького НАН України, 2011. 448 с. С. 296.

25 Митний кодекс України : Закон України від 13.03.2012 p. Відомості Верховної Ради Украӥни. 2012. № 44-45, № 46-47, № 48. Ст. 558.
} 
the development of legislation. Although the Constitution of Ukraine doesn't contain any rules that would directly regulate the issues of the activity of customs authorities, it defines the basic principles of activity of state bodies and the scope of fundamental rights and freedoms of a person. Article 17 of the Constitution of Ukraine stipulates that the security of the state security and the protection of the state border of Ukraine shall be vested in the respective military formations and law enforcement bodies of the state, the organization and procedure of which are determined by law; Art. 19 requires state authorities and their officials to act only on the grounds, within the powers and in the manner provided by the Constitution of Ukraine and laws; and Art. 92 contains a clear indication that the laws of Ukraine exclusively determine the principles of external relations, foreign economic activity, customs and the legal regime of the state border. At the same time, the only legislative body in Ukraine is the Parliament - the Verkhovna Rada of Ukraine, whose exclusive competence is the adoption of legislative acts that have the highest legal force and which must be consistent with the legal acts of all other state bodies ${ }^{26}$. Scientists have determined that "the fulfillment of their functions in the formulation of customs policy the Verkhovna Rada of Ukraine performs in accordance with the Constitution, laws of Ukraine, the Verkhovna Rada Regulation through lawmaking - a process that results in the issuance of normative legal acts containing certain legal rules governing the relevant group, social and legal relations. In other words, the function of the Verkhovna Rada in the formulation and implementation of customs policy is its legislative support ${ }^{27}$.

We can find confirmation of this directly in Customs Code of Ukraine, in particular, Art. 7 defines the importance of laws (as a form of expression of the rules of law) in customs law, clearly specifying that the principles of state customs, including the legal status of customs authorities, customs territory and customs border, procedures for customs control and clearance, customs regimes and conditions of their application, prohibitions and restrictions on the movement of certain types of goods, the terms and procedure for customs duties are determined by the Customs Code and other laws of Ukraine. At the same time, scientists point out some imperfection of the current Customs Code, especially on normative models of legal procedure, which leads to the constant issuance of a large number

26 Конституція України: прийнята на п'ятій сесії Верховної Ради України 28.06.1996 р. Відомості Верховної Ради України. 1996. № 30. Ст. 141.

27 Ківалов С.В., Кормич Б.А. Митна політика України. Одеса: Юрид. літ., 2001. 256 c. C. 124. 
of by-laws, which interpret or clarify the basic customs procedures, thereby reducing the effectiveness of the system of rules of law on issues customs activities, causing dissatisfaction with customs officials and customers ${ }^{28}$.

The Verkhovna Rada of Ukraine has the opportunity to adopt legal acts on customs matters, and its powers to regulate in the specified field are exercised, through the adoption of laws and regulations. In view of the practical aspects of modern law-making, the instability of legislation is not only recognized as a serious problem, but also determined by the most important among the corruption risks that arise in the process of its application. A. Busol noted to such a critical sign that the overwhelming majority of the laws that were adopted were aimed at amending the existing laws, and some laws were amended more than 100 times $^{29}$.

The leading role of the Verkhovna Rada of Ukraine in the process of adaptation of national customs legislation to the norms of international law cannot be overlooked, since this body is empowered to develop and adopt legislative acts - both of a special nature, regarding the acceptance of obligations and the implementation of specific international treaties and general character. In addition, the Parliament of Ukraine exercises other powers important for the implementation of the rules of international customs law: granting consent to the bindingness of international treaties of Ukraine, denouncing them, exercising parliamentary control over the fulfillment of international obligations, etc. Thus, laws, as a form of expression of legal norms, play a leading role in regulating the activities of customs authorities. However, customs legislation is not limited to laws.

Exploring the by-law level of legal regulation of customs activity in Ukraine, it should be reminded that the by-law normative legal act is an act issued in accordance with the law, on the basis of the law, for specifying legislative orders and their interpretation or establishment of primary rules, but less legal force. Such acts, in the opinion of A. Skakun, don't mean less legal obligation and they occupy an important place in the whole system of legal regulation. Among the by-laws, through which the legal regulation of the activity of domestic customs bodies is carried out, the highest share belongs to the acts of such higher authorities as the Cabinet of Ministers of Ukraine and the President of Ukraine.

\footnotetext{
28 Кунєв Ю.Д. Проблеми дослідження правових аспектів організації діяльності митної служби. Вісник Академії митної служби Украӥни. Серія: «Право». 2011. № 1. С. 63-71. C. 64 .

29 Бусол О.Ю. Протидія корупційній злочинності в Україні у контексті сучасної антикорупційної стратегії : автореф. дис. ... д-ра юрид. наук. Київ, 2015. 36 с. С. 15.
} 
According to Art. 49 of the Law of Ukraine "On the Cabinet of Ministers of Ukraine" the government issues binding acts - resolutions and orders ${ }^{30}$. Such acts are issued in two forms: normative in the form of resolutions, and on organizational and administrative and other current issues - in the form of orders of the Cabinet of Ministers of Ukraine. Given that the orders of the Cabinet are not normative in nature, and therefore, and cannot set rules of conduct for participants in customs relations, in our study they will not be studied.

The Constitution of Ukraine stipulates that the Cabinet of Ministers of Ukraine is the supreme body in the system of bodies of executive power, and its powers include issues of activities of customs bodies, including: taking measures to ensure the rights and freedoms of the individual and the citizen; ensuring the implementation of financial, price, investment and tax policies; policies in the fields of nature protection, environmental safety and environmental management; development of the project and ensuring implementation of the State Budget; implementation of measures to ensure national security, public order, fight against crime; organization and maintenance of foreign economic activity and customs. The Cabinet of Ministers of Ukraine directs and coordinates the work of ministries and other executive bodies, including on customs matters. Such managerial activity occurs within the powers of the government and provides for: implementation of tariff measures of regulation of the FEA by setting the amount of customs duties and payment for customs procedures; implementation of nontariff measures of regulation of foreign economic activity through adoption of legal acts in the field of licensing and quotas; coordinating the activities of ministries, other executive authorities, the State Customs Service and other supervisory authorities on issues related to the movement of goods across the customs border; conducting negotiations and concluding international treaties on customs issues.

Similar rules are contained in point 8 of Art. 2 of the Law of Ukraine "On the Cabinet of Ministers of Ukraine" and Art. 20 of this Law, in addition to the above positions, specifies that the Government not only organizes and ensures the implementation of customs affairs, but also has a number of powers that directly or indirectly affect the activities of customs authorities and economic entities and citizens who move goods through customs border.

30 Про Кабінет Міністрів України : Закон України від 27.02.2014 p. № 794-VII. Відомості Верховної Ради України. 2014. № 22. Ст. 222. 
The blanket nature of a number of norms of the Customs Code of Ukraine allows regulate certain issues related to the definition of procedures and procedures for carrying out certain types of activities, moving across the border of certain objects or the implementation of customs formalities, the Cabinet of Ministers of Ukraine by issuing relevant regulations on such issues. By Resolutions of the Cabinet of Ministers regulate: the procedure of information exchange on the principle of "single window" (Article 33); the procedure for verification of certificates and declarations of origin (Article 47); the procedure for conducting the Ukrainian classification of FEA goods (Article 68); a list of border crossing points at which goods are moved (Article 195); the amount of payment for customs formalities (Article 247); provisions on customs declarations and their forms (Article 257); the list of goods the transit of which is carried out under the condition of payment of customs duties (Article 305); typical technological schemes of customs control (Article 318); the procedure for carrying out preliminary documentary control (Article 319); an exhaustive list of grounds upon which goods and vehicles may be inspected (Article 338); volumes and procedure for importing medicinal products (Article 318); 370); a list of prohibited goods and the procedure for the export of precious metals and cultural property (Article 373); rules for the sale of goods by duty-free shops (Article 420); uniforms and standards for providing them (Article 552); the procedure of holding working meetings of the customs authorities with representatives of the customs authority of a neighboring foreign state (Article 566); the procedure for conducting a competition for admission to the civil service in the customs authorities (Article 570); provisions on special ranks of officials (Article 573); the list of special means and the procedure for their application (Article 583); the size and procedure of setting the salaries of customs officials (Article 585) and a number of other issues.

In addition to the above issues, the Cabinet regulates the legal relations arising in the course of interaction of customs authorities with other state bodies and citizens; to the full extent the rules of legal acts concerning the organization of work on combating corruption, passing the civil service, including entry into such service, promotion to higher positions in terms of competitive selection, evaluation of the results of official activity, improvement of professional competence are subject to the activity of customs authorities and their officials. In addition, the issue of the creation, liquidation and reorganization of customs authorities, as well as the approval of the provision of a central authority 
in the field of customs policy implementation, are also within the scope of government.

By Resolutions of the Cabinet of Ministers of Ukraine were established the State Customs Service of Ukraine ${ }^{31}$, approved the order of the State Customs Service ${ }^{32}$ and formed the territorial bodies of the customs service (including customs posts as separate structural units of the customs). As we can see, the Government regulates customs activities in two directions: at first, as an influence on the organization of movement of goods and objects across borders, and second, as an influence on the functioning of the customs authorities themselves and the activities of their officials.

An important place in the legal regulation and management of the organization of customs authorities is the President of Ukraine, who issues decrees and orders that are binding on the territory of Ukraine. Although in some cases it is necessary to agree with critical remarks about the presence of a certain nihilistic potential in regulating the activity of leading executive bodies by Presidential Decrees, the President takes part in regulating the issues of organization and activity of customs bodies, which can be illustrated by the following:

- the State Customs Committee of Ukraine was formed in 1991 and the Temporary Regulation on this body ${ }^{33}$ was approved; later in a similar manner were approved: in 1995 - the Regulations on the State Customs Committee ${ }^{34}$, and in 2000 - the Regulations on the State Customs Service $^{35}$;

- in 2007, to implement the Law of Ukraine "On Ukraine's Accession to the Protocol on Amendments to the International Convention on the Simplification and Harmonization of Customs Procedures", measures were introduced to strengthen the European integration of border cooperation $^{36}$;

31 Про утворення Державної податкової служби України та Державної митної служби України : Постанова Кабінету Міністрів України від 18 грудня 2018 р. № 1200.

32 Про затвердження положень про Державну податкову службу України та Державну митну службу України : Постанова Кабінету Міністрів України від 6 березня 2019 р. № 227.

33 Про утворення Державного митного комітету України : Указ Президента України від 11.12.1991 p. № 1. URL: http://zakon2.rada.gov.ua/ laws/show/1/91.

34 Положення про Державний митний комітет України : Указ Президента України від 20.01.1995 p № 73/95. URL: http://2akon4.rada.gcw.ua/ laws/show/73/95.

35 Положення про Державну митну службу України: Указ Президента України від 24.08.2000 р. № 1022/2000. Офічійний вісник Украӥни. 2000. № 35. Ст. 1477.

36 Про заходи щодо активізації євроінтеграційного прикордонного співробітництва: Указ Президента України від 19.12.2007 р. № 1236/2007. URL: http://zakon2.rada.gov.ua/laws/ show/1236/2007. 
- in 2008, a program for combating smuggling and customs violations for 2008-2009, known as program "Smuggling - stop", was approved $^{37}$;

- in 2011, a procedure was initiated to amend some legislative acts on the application of Incoterms ${ }^{38}$ rules;

- in 2012, as a result of the reorganization of the State Customs Service and the State Fiscal Service, the Ministry of Revenue and Duties of Ukraine ${ }^{39}$ was formed, and in 2013, the Regulations on it were approved ${ }^{40}$.

The next group of secondary legal sources consisting of departmental regulations. Such orders contain secondary rules that specify the primary rules of law established by law. Typically, these acts have interdepartmental legal value, issued only on matters which are the responsibility of central executive bodies and in accordance distributed to officers and employees of the department. The necessity of issuing departmental orders is conditioned by a number of factors, the main among which are: a direct indication of a legal act on the issuance of an act of a certain form to specify a specific rule of law; lack of clear definition of the rights and obligations of the entities; gaps in the regulation of legal relations, etc. N. Parkhomenko supplements the above list with several more positions and considers that the departmental rule-making is caused by the absence of the mechanism of implementation of laws and the inaccuracy of the definition of lawmaking powers, the imperfection of legal technique ${ }^{41}$.

L. Davydenko noted that the peculiarity of the customs legislation is a large number of departmental normative acts that regulate customs procedures. The researcher believed that "with their help, they are filled with the actual content of the normative laws, which, having a much longer" life "than by-laws, perform mainly only a general role, while procedures

37 Про програму боротьби 3 контрабандою та порушеннями митних правил на 2008-2009 роки : Указ Президента України від 04.03.2008 p. № 195. URL: https://zakon.rada.gov.ua/laws/show/195/2008.

38 Про визнання такими, що втратили чинність, Указів Президента України від 04 жовтня 1994 р. № 567 і від 01 липня 1995 р. № 505 : Указ Президента України від 19.05.2011 р. № 589/2011. Офіційний вісник Украӥни. 2011. № 39. Ст. 1594.

39 Про деякі заходи з оптимізації системи центральних органів виконавчої влади : Указ Президента України від 24.12.2012 р. № 726/2012. URL: http://zakon4.rada.gov.ua/laws/ show/726/2012.

40 Про Міністерство доходів і зборів України : Указ Президента України від 18.03.2013 p. № 141/2013. Офіційний вісник Украӥни. 2013. № 22. Ст. 739.

41 Пархоменко Н. Законодавство України на сучасному етапі: кількісний та якісний аналіз. Публічне право. 2012. № 3 (7). С. 291-298. С. 293. 
often require specific regulation and surgery, and therefore, their value is difficult to overestimate ${ }^{42}$.

Among the positive features of departmental acts, it is customary to distinguish the relative speed of their adoption, sufficient flexibility and mobility, coverage of different aspects of social relations, speed of implementation of the requirements of such acts, etc. At the same time, over-explicit enthusiasm for the creation of departmental orders, orders, instructions and recommendations is considered an indicator of such negative phenomena as excessive regulation of social relations and poor quality of the adopted laws.

Without reducing the role of by-laws in the regulation of public relations, scientists pay attention to the tendency of unjustified increase in the volume of subordinate law-making, urge more deliberate approach to the issuance of by-laws in view of their binding to the law, the timing. The analysis of legal practice made by scientists allowed the scientist to make a critical conclusion about the neglect of legislative norms by the subjects of subordinate and local rulemaking and giving preference to departmental regulation ${ }^{43}$.

Thus, if in 2012 it was noted that the share of departmental rulemaking in such a process is increasing, in 2015, on issues related to law-making in the customs case, there was a gradual restriction on the implementation by the customs service of such activity ${ }^{44}$. Therefore, to find out the place and role of the central law-enforcement agency in customs, let us turn to the main stages of the gradual limitation of the authority to prepare regulations.

The Regulation on the State Customs Committee of Ukraine, approved by the Decree of the President of Ukraine of January 20, 1995, provided that the State Customs Committee, within the limits of its powers, issues orders, organizes and controls their execution on the basis and on the implementation of the legislation of Ukraine.

Five years later, in August 2000, after the establishment of the State Customs Service of Ukraine as the central executive authority, the State Customs Service of Ukraine has the right to issue orders, organize and control their execution (including, issue, orders) joint acts with other executive

\footnotetext{
42 Давиденко Л.М. Забезпечення прав і свобод громадян при здійсненні митних процедур (організаційно-правові аспекти) : дис. ... канд. юрид. наук. Ірпінь, 2007. 209 с. С. 173.

43 Пархоменко Н. Законодавство України на сучасному етапі: кількісний та якісний аналіз. Публічне право. 2012. № 3 (7). С. 291-298. С. 293.

44 Дукова Н.М. Правотворчість фіскальної (митної) служби: історичні аспекти та сучасний стан. Митна справа. 2015. № 2. С. 29-34. С. 31.
} 
bodies). At the same time, a requirement was made for mandatory registration of normative legal acts of the State Customs Service.

P. 7 of the Regulations on the State Customs Service of Ukraine adopted in 2007, retaining the powers of the State Customs Service to issue orders, organize and control their execution, specified that this was done within the limits of their powers on the basis of and on the implementation of acts of the legislation, and draft normative acts of the Service subject to state registration agree with the Minister of Finance.

Based on the in-depth consideration of the expected consequences of subordination of the State Customs Service of the Ministry of Finance back in 2005, I. Pismen has proved that the Ministry of Finance should have normatively assigned coordinating and integrating functions for the implementation of strategic directions of customs policy, solving all operational issues of the service ${ }^{45}$. The opposite was the opinion of L. Davydenko, who considered the norms of customs legislation to be far from perfect, demanded urgent steps to improve it, which necessitated the gradual transition from regulation of customs procedures to mostly departmental acts to legislative regulation ${ }^{46}$. We have also previously studied the issues of regulatory support of customs, in connection with which we can note that not only the State Customs Service, as a central body, but also subordinate customs bodies as subjects of normalization, conducted state registration of legal acts (procedures, technologies and technological schemes of customs control and registration, provisions on the creation of customs control zones, etc.), which contained norms that affected the rights, freedoms and legitimate interests of citizens or had an interagency nature. Practically, there were tens to hundreds of orders in each customs office that had been registered in the period 2005-2011.

As a result of the administrative reform initiated in 2010 and the adoption of the Law of Ukraine "On Central Executive Bodies" and regulation of some issues related to the organization of work of ministries and other central executive bodies, the procedure for issuing regulatory acts was changed. Ministries that defined priority areas of development and ensured legal regulation were granted this right, while other central executive bodies could issue only orders of an organizational and regulatory nature within the limits of their powers. In fact, during this period the State Customs Service's

45 Письменний І.В. Концептуальні засади реформування митної служби України : дис. ... канд. наук $з$ держ. упр. Дніпропетровськ, 2005. 220 с. С. 194.

46 Давиденко Л.М. Забезпечення прав і свобод громадян при здійсненні митних процедур (організаційно-правові аспекти) : дис. ... канд. юрид. наук. Ірпінь, 2007. 209 с. С. 78. 
independence in adopting normative acts ceases. With the entry into force of the aforementioned law and the approval by the Cabinet of Ministers on 25 May 2011 of the "Model Regulations on Territorial Bodies of the Ministry and Other Central Executive Bodies", the customs authorities have lost the right to create their own normative-legal acts to regulate customs matters.

By the Decree of the President of Ukraine of April 8, 2011 No. 446/2011 "On the Regulation on the Ministry of Finance of Ukraine", the implementation of regulatory and legal regulation in the financial, budgetary, tax and customs spheres is within its exclusive competence. From that time on, the Ministry became the entity that issued departmental regulations to regulate public relations in the customs sector. Since May 2011 the State Customs Service of Ukraine, within the limits of its powers, on the basis of and in compliance with the Constitution and laws of Ukraine, acts and instructions of the President of Ukraine, acts of the Ministry of Finance of Ukraine and orders of the Minister issues only orders of organizational and administrative nature ${ }^{47}$.

As you can see, in 2011, there were a number of changes in the legislation governing the preparation of regulatory acts, which are guided by officials of customs authorities in the implementation of customs formalities and other issues related to the implementation of customs. As this didn't take into account the peculiarities of the formation of the departmental regulatory base of the customs authorities for the previous 20 years, the customs faced the problem of the recognition of invalid orders (including joint ones with other bodies) for which state registration was conducted. It is quite logical that the Minister of Finance could have done this, however this issue has not found its legal implementation. In our opinion, the delegation of authority to adopt departmental normative legal acts to a subject (Ministry of Finance), which does not ensure the implementation of state customs, and therefore does not have specialized specialists, on the one hand, increased the level of demand for the process of preparation and approval of drafts of such documents and, on the other, led to a slowdown in response to departmental issues.

From December 2012 to March 2014, the Ministry of Revenue and Duties of Ukraine formed as a result of the merger of the State Customs Service and the State Tax Service existed as the central executive body. According to item 9 of the Ministry's Regulations, this body, within the limits of its powers, on the basis of and in compliance with the Constitution

47 Положення про Державну митну службу України : Указ Президента України від 12.05.2011 р. (втратив чинність). Офічійний вісник Украӥни. 2011. № 37. Ст. 1514; Про затвердження Положення про Міністерство фінансів України : Постанова Кабінету Міністрів України від 27.12.2006 р. № 1837. Офіщійний вісник Украӥни. 2007. № 1. Ст. 26. 
and laws of Ukraine, acts and instructions of the President of Ukraine, acts of the Cabinet of Ministers of Ukraine issued orders, organized and supervised their implementation.

In May 2014, through the reorganization of the Ministry of Revenue, the State Fiscal Service was formed, which, on the basis and on the implementation of the Constitution and laws of Ukraine, acts of the President of Ukraine, resolutions of the Cabinet of Ministers of Ukraine, orders of the Ministry of Finance, issues orders of organizational and administrative character, organizes and controls them performance ${ }^{48}$. Having lost the status of a ministry, the service is accordingly deprived of authority to formulate public policy in a particular field. The newly created State Customs Service of Ukraine, which became operational in December 2019, has a similar status. Assessing the above in combination with the requirements of Part 1 of Art. 23 of the Law on Central Executive Bodies we state that the fiscal service within its authority issues orders, but only of an organizational and administrative nature.

Central executive bodies are formed to perform certain functions for the implementation of state policy as a service, agency, inspection, and their activity is directed and coordinated by the Cabinet of Ministers of Ukraine through the respective ministers in accordance with the legislation. Accordingly, the State Customs Service of Ukraine is the central body of executive power, which implements the state customs policy, directs, coordinates and controls the activities of customs, exercises other powers provided by the Customs Code and other laws of Ukraine, within its authority issues orders, organizes and controls their implementation. The main tasks of the State Customs Service include: ensuring the implementation of the state customs policy, in particular, ensuring the customs security and protection of Ukraine's customs interests and creating favorable conditions for the development of foreign economic activity, maintaining a proper balance between customs control and facilitation of legal trade; ensuring the implementation of state policy in the field of combating offenses in the application of the legislation on state customs, prevention and counteraction to smuggling, combating violations of customs rules; as well as submitting proposals to ensure the formation of the state customs policy for consideration by the Minister of Finance ${ }^{49}$.

48 Про Державну фіскальну службу України : Постанова Кабінету Міністрів України від 21.05.2014 p. № 236. URL: http://zakon2.rada.gov.ua/laws/show/236-2014-П.

49 Положення про державну митну службу України : Постанова Кабінету Міністрів України від 6 березня 2019 р. № 227. URL: https://zakon.rada.gov.ua/laws/show/227-2019-п. 
So, the State Customs Service does not formulate, but only implements the state customs policy and makes proposals to ensure the formation of such a policy to the Ministry of Finance. The Ministry of Finance is the main body in the system of central bodies of executive power, which ensures the formation and implementation of a unified state tax, customs policy, state policy in the sphere of combating offenses in the application of tax and customs legislation ${ }^{50}$. In accordance with the tasks assigned to it, the Ministry of Finance: generalizes the practice of applying the legislation on issues within its competence, develops proposals for improvement of legislative acts, acts of the President of Ukraine, the government and submits them to the Cabinet of Ministers of Ukraine in due course; and develops draft laws and regulations on matters within its competence.

The law-making of the customs service has already been studied by domestic scientists, however, and we would like to supplement the systematic classification proposed earlier by N. Dukov not only on the factor of independence in issuing orders. It seems important to us to characterize the departmental regulatory legal support in the customs sphere, taking into account the type of central body and the form of acts which it is authorized to issue. Of course, such systematization should take into account both the evolution of the development of executive bodies as subjects of law-making, and the requirements for legal examination of acts in accordance with the Constitution and legislation of Ukraine, the Convention on the Protection of Human Rights and Fundamental Freedoms of 1950, international treaties of Ukraine and obligations. European integration and European Union law (EU acquis), as well as anti-corruption expertise.

In our opinion, in the system of customs authorities of Ukraine it is possible to distinguish the following stages of agency normalization:

1991-1996 - the State Customs Committee has the authority to issue orders, including those of a regulatory nature;

1997-2007 - the State Customs Service has similar powers;

2007 - May 2011 - the State Customs Service issues orders, with those of a regulatory nature and subject to state registration agreeing with the Ministry of Finance;

2011-2012 - the State Customs Service is authorized to issue orders of an organizational and administrative nature only, and the Ministry

\footnotetext{
50 Про затвердження Положення про Міністерство фінансів України : Постанова Кабінету Міністрів України від 20.08.2014 p. № 375. URL: http://zakon4.rada.gov.ua/laws/show/3752014-п.
} 
of Finance may issue departmental normative acts in the sphere of customs relations;

2013- May 2014 - the Ministry of Revenue and Duties of Ukraine has the authority to regulate customs in the customs sector and issue orders of a regulatory nature;

2014-2019 - the State Fiscal Service of Ukraine issues orders of an organizational and administrative nature only, and the Ministry of Finance has the right to issue departmental regulations in the customs sphere relations;

2019-2020 - the State Customs Service of Ukraine, by analogy with the State Fiscal Services, carries out departmental regulation by issuing organizational and administrative acts.

Today, among the local regulations of a regulatory nature, which regulate certain issues of the activities of bodies that directly ensure the implementation of state customs, are orders of the State Customs Service of Ukraine (1997-2010), the Ministry of Revenue and Duties of Ukraine, the Ministry of Finance of Ukraine. The same list includes even several orders of the State Fiscal Service of Ukraine on organization of functioning of the units of own security, the issue and validity of which are quite controversial because they, in our opinion, contain norms that affect the rights of individual citizens. The orders of the new State Customs Service issued in the period 2019-2020 are also not deprived of this deficiency.

\section{CONCLUSIONS}

The normative acts which are actually a constituent part of the customs legislation of Ukraine can be divided into two big groups: domestic legislation and international sources that regulate legal relations in the customs sphere. The first group include laws (including the Constitution of Ukraine and Customs Code of Ukraine), by-laws (decrees and decrees of the President of Ukraine, decrees and decrees of the Cabinet of Ministers, departmental orders (State Customs Service of Ukraine, Ministry of Finance of Ukraine, Ministry of Revenue and Duties of Ukraine, State Fiscal services of Ukraine), etc. The second group is formed from acts of international law (international conventions and agreements, various memoranda, protocols, etc.), which establish the procedure for Ukraine's interaction with other countries, customs unions and international institutions on issues related to the movement of goods and objects across borders, or country involvement in international organizations. 
Ukraine's internationally ratified treaties become the norms of national law, and the chosen course for European integration obliges to adapt the rest of domestic legislation to international standards. Here, the most significant achievement was the implementation of the international standards of the Kyoto Convention on the simplification and harmonization of customs procedures by adopting in March 2012 a new version of Customs Code of Ukraine, which contains the maximum number of norms of direct action that are aligned with its requirements. In the course of this scientific study of legal support of customs activity it's found out that the departmental rulemaking in the course of permanent transformation of the system of bodies forming and implementing the state customs policy doesn't differ in sequence and completeness, and the system of customs legislation consists of a large number of different types, forms and regulatory publishers. Nevertheless, in the context of globalization and European integration processes, international and European standards of activity of customs administrations become the main guidelines for improving customs legislation.

\section{SUMMARY}

This article is dedicated to investigation the mechanisms of formation of the system of normative acts in the customs sphere. There are analyzed the general principles of legal regulation the relations, which are formed in time when goods have crossed the customs border and during the activity of the customs authorities. The main elements of Ukrainian customs legislation have been identified in view of the form of sources and legal personality authorized for their adoption by state bodies. Such rules were divided into two types: domestic legislation and international sources which regulate legal relations in the customs sphere.

Based on the analysis of legal regulation conducted in the context ofinstitutionaldevelopment ofUkrainiancustomsauthorities, thepeculiarities of administrative and legal regulation in the sphere of customs are revealed, and the entities involved in customs management and entering into legal relations with the entities of public administration are distinguished.

During the research have concluded the opinion that the system of customs legislation of Ukraine consists of a large number of different types, forms and publishers of regulations and departmental rulemaking through the permanent transformation of the bodies that form and implement state customs policy is not always consistent and complete.

In the context of globalization and European integration processes, international and European standards of activity of customs 
administrations become the main guidelines for the improvement of customs legislation.

\section{REFERENCES}

1. Авер'янов В.Б. Вибрані наукові праці / упоряд.: О.Ф. Андрійко, В.П. Нагребельний, Л.С. Кисіль та ін. ; за заг. ред. Ю.С. Шемшученка, О.Ф. Андрійко. Київ: Ін-т держави і права ім. В.М. Корецького НАН України, 2011. 448 с.

2. Акіменко Ю.Ю. Деякі аспекти гармонізації національного законодавства, що регулює діяльність господарських товариств у контексті створення зони вільної торгівлі між Україною та Свропейським Союзом. Зона вільної торгівлі Украӥна - Свропейський Союз та європейська інтеграція: правові та економічні аспекти : зб. статей учасників міжнар. наук.-практ. конф. (м. Одеса, 08 черв. 2007 р.) / відп. ред. М.П. Орзіх. Одеська національна юридична академія; Б-ка журналу «Юридический вестник». Одеса : Фенікс, 2007. С. 75-79.

3. Бусол О.Ю. Протидія корупційній злочинності в Україні у контексті сучасної антикорупційної стратегії : автореф. дис. ... д-ра юрид. наук. Київ, 2015. $36 \mathrm{c.}$

4. Василенко В.М. Реалізація принципу «єдиного вікна» у здійсненні контролю за переміщенням окремих видів товарів через митний кордон України. Форум права. 2015. № 1. С. 38-41.

5. Глазунова Н.И. Государственное управление как система : монография. Москва : Изд-во Гос. ун-та управления, 2001. 373 с.

6. Гомонай В.В. Зближення законодавства України 3 правовою системою Європейського Союзу. Держава і право. Юридичні і політичні науки : зб. наук. праць. Київ : Ін-т держави і права ім. В.М. Корецького НАН України, 2009. Вип. 44. С. 204-212.

7. Горюнова Є.О. Євроінтеграція : навчальний посібник. Київ : Академвидав, 2013. 224 с.

8. Давиденко Л.М. Забезпечення прав і свобод громадян при здійсненні митних процедур (організаційно-правові аспекти) : дис. ... канд. юрид. наук. Ірпінь, 2007. 209 с.

9. Денисенко В.В. Правове забезпечення митної політики: міжнародно-правові стандарти та українське законодавство : навчальний посібник. Запоріжжя : ЗНТУ, 2018. 326 с.

10. Дукова Н.М. Правотворчість фіскальної (митної) служби: історичні аспекти та сучасний стан. Митна справа. 2015. № 2. С. 29-34.

11. Іванов О.В. Суб'єкти адміністративно-правового регулювання в галузі митної справи : дис. ... канд. юрид. наук. Запоріжжя, 2015. $205 \mathrm{c}$. 
12. Ківалов С.В., Кормич Б.А. Митна політика України. Одеса : Юрид. літ., 2001. $256 \mathrm{c.}$

13. Клян Ф.Г. Міжнародно-правове регулювання переміщення товарів через митний кордон : дис. ... канд. юрид. наук. Київ, 2011. 197 с.

14. Коломоєць О.В. Митна функція сучасної української держави: загальнотеоретичне дослідження : дис. ... канд. юрид. наук. Одеса, 2014. $205 \mathrm{c}$.

15. Комзюк В.Т. Адміністративно-правовий статус митних органів України : дис. ... д-ра юрид. наук. Харків, 2014. 446 с.

16. Конституція України: прийнята на п'ятій сесії Верховної Ради України 28.06.1996 р. Відомості Верховної Ради України. 1996. № 30. Ст. 141.

17. Кормич Б.А. Глобалізація адміністративного права та митне законодавство. Lex Portus. № 5 (7). 2017. C. 17-29.

18. Кунєв Ю.Д. Проблеми дослідження правових аспектів організації діяльності митної служби. Вісник Академії митної служби України. Серія «Право». 2011. № 1. С. 63-71.

19. Ладлоу Г., Дженкінз Д., Морт Е. Реформування Державної митної служби: звіт місії відділу бюджетно-фінансових справ (ВБФС). Міжнародний валютний фонд. Січень, 2006. 110 с.

20. Митний кодекс України : Закон України від 13.03.2012 р. Відомості Верховної Ради України. 2012. № 44-45, № 46-47, № 48. Ст. 558.

21. Міжнародна конвенція про спрощення та гармонізацію митних процедур у редакції від 26 червня 1999 р. Офіційний вісник Украӥни. 2011. № 71/№ 18. Ст. 727, Ст. 2711.

22. Настюк В.Я. Адміністративно-правові проблеми законодавчого регулювання митної справи в Україні : автореф. дис. ... д-ра юрид. наук. Харків, 2005. $36 \mathrm{c.}$

23. Пархоменко Н. Законодавство України на сучасному етапі: кількісний та якісний аналіз. Публічне право. 2012. № 3 (7). С. 291-298.

24. Письменний І.В. Концептуальні засади реформування митної служби України : дис. ... канд. наук з держ. упр. Дніпропетровськ, 2005. 220 с.

25. Положення про Державний митний комітет України : Указ Президента України від 20.01.1995 р № 73/95. URL: http://2akon4.rada.gcw. ua/laws/show/73/95.

26. Положення про державну митну службу України : Постанова Кабінету Міністрів України від 6 березня 2019 р. № 227. URL: https://zakon.rada.gov.ua/laws/show/227-2019-п.

27. Положення про Державну митну службу України : Указ Президента України від 24.08.2000 р. № 1022/2000. Офічійний вісник України. 2000. № 35. Ст. 1477. 
28. Положення про Державну митну службу України : Указ Президента України від 12.05.2011 р. (втратив чинність). Офіційний вісник України. 2011. № 37. Ст. 1514.; Про затвердження Положення про Міністерство фінансів України : Постанова Кабінету Міністрів України від 27.12.2006 p. № 1837. Офіційний вісник Украӥни. 2007. № 1. Ст. 26.

29. Про визнання такими, що втратили чинність, Указів Президента України від 04 жовтня 1994 р. № 567 і від 01 липня 1995 р. № 505 : Указ Президента України від 19.05.2011 р. № 589/2011. Офіиійний вісник України. 2011. № 39. Ст. 1594.

30. Про внесення змін до Митного кодексу України та деяких інших законів України щодо запровадження механізму «єдиного вікна» та оптимізації здійснення контрольних процедур при переміщенні товарів через митний кордон України : Закон України від 06.09.2018 p. № 2530-VIII. URL: http://zakon.rada.gov.ua/laws/show/2530-19.

31. Про Державну фіскальну службу України : Постанова Кабінету Міністрів України від 21.05.2014 p. № 236. URL: http://zakon2.rada.gov.ua/ laws/show/236-2014-п.

32. Про деякі заходи 3 оптимізації системи центральних органів виконавчої влади : Указ Президента України від 24.12.2012 р. № 726/2012. URL: http://zakon4.rada.gov.ua/laws/show/726/2012.

33. Про затвердження Положення про Міністерство фінансів України : Постанова Кабінету Міністрів України від 20.08.2014 р. № 375. URL: http://zakon4.rada.gov.ua/laws/show/375-2014-\%D0\%BF.

34. Про затвердження положень про Державну податкову службу України та Державну митну службу України : Постанова Кабінету Міністрів України від 6 березня 2019 р. № 227.

35. Про заходи щодо активізації євроінтеграційного прикордонного співробітництва : Указ Президента України від 19.12.2007 р. № 1236/2007. URL: http://zakon2.rada.gov.ua/laws/show/1236/2007.

36. Про Кабінет Міністрів України : Закон України від 27.02.2014 p. № 794-VII. Відомості Верховної Ради України. 2014. № 22. Ст. 222.

37. Про Міністерство доходів і зборів України: Указ Президента України від 18.03.2013 р. № 141/2013. Офіційний вісник України. 2013. № 22. Ст. 739.

38. Про програму боротьби з контрабандою та порушеннями митних правил на 2008-2009 роки : Указ Президента України від 04.03.2008 р. № 195. URL: https://zakon.rada.gov.ua/laws/show/195/2008.

39. Про реалізацію експериментального проекту щодо створення умов для унеможливлення ухилення від сплати митних платежів : Постанова Кабінету Міністрів України від 20.06.2018 р. № 479. URL: http://zakon.rada.gov.ua/laws/show/479-2018. 
40. Про утворення Державного митного комітету України: Указ Президента України від 11.12.1991 p. № 1. URL: http://zakon2.rada.gov.ua/ laws/show/1/91.

41. Про утворення Державної податкової служби України та Державної митної служби України : Постанова Кабінету Міністрів України від 18 грудня 2018 р. № 1200.

42. Русских Т.В. Концепція норм м'якого права у сфері регулювання митних відносин в Україні : дис. ... канд. юрид. наук. Одеса, 2015. 176 с.

43. Скакун О.Ф. Теорія держави і права : підручник / пер. з рос. Харків : Консум, 2006. 656 c.

44. Ярмакі Х.П. Адміністративно-наглядова діяльність міліції в Україні : монографія. Одеса : Юрид. л-ра, 2006. 366 с.

45. International Convention Relating to the Simplification of Customs Formalities. Geneva, November 3, 1923. League of Nations. Treaty Series. Vol. 30. 1924-1925. P. 371.

Information about the authors:

Dorofeieva L. M., Doctor of Law, Professor of the Department of Administrative, Finance and Information Law Uzhhorod National University 3, Narodna Square, Uzhhorod, Ukraine

Korneva T. V., $\mathrm{PhD}$ in Law, Associate Professor of the Department of Constitutional Law and Industry Disciplines National University of Water Management and Environmental Engineering 79, O. Novaka str., Rivne, Ukraine

DOI https://doi.org/10.30525/978-9934-588-43-3/2.3 